\title{
PENGARUH PERASAN KULIT JERUK NIPIS TERHADAP DAYA HAMBAT BAKTERI STREPTOCOCCUS MUTANS
}

\author{
Irmanita Wiradona1, Suwarsono' ${ }^{2}$, Novi Anna Zakiyatul ${ }^{3}$
}

\begin{abstract}
The caries disease dental and oral health problems are high in Indonesia. The cause of caries disease one of which is the bacterium Streptococcus mutans. Efforts to prevent one of them with natural ingredients that lime peel. In lime peel essential oils are substances that are useful as antibacterial and phenols contained in the essential oil can denature bacterial cell proteins. The objective of this the effect of lime juice on the skin inhibition of Streptococcus mutans bacteria.

This is a quasi experimental study (quasi-experimental). Research subjects bacterium Streptococcus mutans. The study was conducted using a concentration of $10 \%, 20 \%, 40 \%$, and $80 \%$ respectively - each concentration done $3 x$ treatment. The data was analyzed with parametric test using ANOVA followed by Post Hoc test.

The results showed a large area of inhibition of the average juice lime peel with a $10 \%$ concentration of $7.73 \mathrm{~mm}$, a $20 \%$ concentration of $9.13 \mathrm{~mm}$, a $40 \%$ concentration of $10.54 \mathrm{~mm}$, and the concentration of $80 \%$ by $14.23 \mathrm{~mm}$. Anova analysis showed a significant $(\mathrm{p}<0.05)$ indicates that there is an influence juice lime peel in inhibiting the growth of Streptococcus mutans.

The higher of the concentration, the greater the inhibition of the bacterium Streptococcus mutans.
\end{abstract}

Key words : Leather Lime Juice, Streptococcus mutans

1,2) Dosen Jurusan Keperawatan Gigi Poltekkes Kemenkes Semarang

3) Mahasiswa Jurusan Keperawatan Gigi Poltekes Semarang

\section{PENDAHULUAN}

Masalah utama kesehatan gigi dan mulut di Indonesia adalah keadaan kebersihan gigi dan mulut yang kurang memenuhi syarat kesehatan sehingga tingginya penyakit karies gigi dan penyakit periodontal. Menurut Riset Kesehatan Dasar atau Riskesdas 2007 bahwa 72,1\% penduduk Indonesia memiliki permasalahan gigi berlubang atau karies, dan 46,5\% diantaranya tidak merawat giginya yang berlubang atau karies tersebut (Depkes RI, 2007).

Karies disebabkan oleh adanya bakteri yang berkoloni di dalam rongga mulut khususnya pada plak gigi dan bakteri tersebut mampu menghasilkan asam sehingga terjadi proses demineralisasi jaringan keras gigi. Salah satu spesies bakteri yang dominan dalam mulut yaitu bakteri Streptococcus mutans (Sabir, 2005). Bakteri inilah yang mengubah glukosa dan karbohidrat pada makanan menjadi asam melalui proses fermentasi. Asam terus diproduksi oleh bakteri dan akhirnya merusak struktur gigi sedikit demi sedikit. Kemudian bakteri akan mengikuti jalan yang sudah dibuat oleh asam dan menginfeksi lapisan gigi (Pratiwi, 2007).

Pencegahan karies dapat dilakukan dengan cara pembersihan plak baik secara mekanis maupun kimiawi. Metode yang digunakan untuk mencegah karies secara mekanis, seperti menyikat gigi, membersihkan gigi menggunakan benang gigi, atau berkumur-kumur dengan menggunakan obat kumur. Pencegahan karies secara kimiawi salah satunya dengan menggunakan zat antibakteri yang dapat menghambat pertumbuhan plak (Kidd dan Joyston, 2002). Zat antibakteri merupakan 
zat yang mampu mengganggu pertumbuhan dan mematikan bakteri (Madigan, 2005). Antibakteri selain dapat diperoleh dari bahan sintetik dapat juga diperoleh secara alami, yaitu dari bahan tradisional.

Beberapa publikasi tentang sifat antibakteri minyak atsiri menyebutkan bahwa komponen minyak atsiri yang tergolong dalam golongan fenolik dan terpenoid mempunyai aktivitas sebagai antibakteri. Hasil penelitian EI-Shazly dan Hussein, (2004) menyebutkan bahwa minyak atsiri Teucrium leucocladum Boiss mempunyai aktivitas antibakteri terhadap bakteri yang diuji (Ecoli, P.aeruginosa, S.aures, B.subtilis, C.albicans). Selain mengandung minyak atsiri, kulit jeruk nipis merupakan sumber yang kaya flavanon dan banyak flavon polymethoxylated (Ahmed et al., 2006).

Penelitian ini digunakan perasan kulit jeruk nipis (Citrus aurantifolia swingle) karena terdapat berbagai fitokemikal yang nantinya bisa dilakukan pengkajian ulang untuk dijadikan sebagai bahan pembuatan obat kumur karena kandungannya yang mampu menghambat pembentukan plak dengan cara menurunkan pembentukan pelikel, menurunkan viskositas dan meningkatkan kecepatan aliran saliva, serta menurunkan jumlah bakteri pembentukan plak yang salah satunya adalah Streptococcus mutans sebagai penyebab gigi berlubang.

Berdasarkan uraian diatas maka perlu dilakukan penelitian apakah perasan kulit jeruk nipis dapat menghambat pertumbuhan bakteri Streptococcus mutans. Tujuan penelitian adalah untuk mengetahui pengaruh perasan kulit jeruk nipis terhadap daya hambat bakteri Streptococcus mutans.

\section{METODE PENELITIAN}

Penelitian ini merupakan quasi experiment (eksperimen semu) dengan rancangan "The One Shot Case Study", dimana peneliti hanya mengadakan perlakuan satu kali (Notoatmodjo, 2012). Dalam penelitian ini, yang diteliti merupakan membandingan jumlah bakteri Streptococcus mutans sesudah mendapat perasan kulit jeruk nipis dengan konsentrasi $10 \%, 20 \%, 40 \%$, dan $80 \%$.

Subyek penelitian yang digunakan adalah bakteri Streptococcus mutans. Variabel penelitian terdiri dari variabel pengaruh yaitu perasan kulit jeruk nipis dengan konsentrasi $10 \%, 20 \%, 40 \%$, dan $80 \%$. Perasan kulit jeruk nipis diperoleh dengan cara mengupas kulit jeruk nipis dari buahnya dan dicuci bersih. Kemudian kulit jeruk nipis dirajang dengan ukuran 0,3$0,5 \mathrm{~cm}$. Kulit jeruk nipis di blender hingga halus. Kulit jeruk nipis yang telah halus dibungkus dengan kain blacu tebal, kemudian diperas dengan tangan memakai handschoen sebanyak dua kali pemerasan, setelah itu diperas menggunakan alat press. Berdasarkan penelitian sebelumnya yang dilakukan oleh Dwi (2012), selama pemerasan kulit jeruk nipis dilakukan penyemprotan dengan air dingin untuk melarutkan minyak atsiri. Hasil yang diperoleh berupa emulsi minyak di dalam air. Minyak kulit jeruk nipis disimpan di dalam botol kaca dalam keadaan tertutup rapat pada tempat yang tidak panas. Variabel terpengaruh penelitian ini adalah daya hambat bakteri Streptococcus mutans. Pengukuran pertumbuhan bakteri adalah dengan mengukur daerah bebas bakteri yang disebut daerah oligodinamik (blank zone). Uji ini dilakukan pada permukaan media padat yaitu $1 \mathrm{ml}$ suspensi bakteri Streptococcus mutans dituangkan di media PCA kemudian diberi paper disk steril yang sebelumnya telah dicelupkan dalam perasan kulit jeruk nipis konsentrasi 10\%, 20\%,40\%, dan $80 \%$ setelah itu diinkubasi selama $1 \times 24$ jam pada suhu $37^{\circ} \mathrm{C}$, dilihat diameter zona penghambatnya yang disebut dengan daerah oligodinamik (blank zone) sebagai daerah bebas bakteri pada cawan petri. Perhitungan daerah bebas bakteri di ukur dengan menggunakan penggaris millimeter. Diameter zona penghambat merupakan pengukuran MIC (Minium Inhibitor Concentration) secara tidak langsung dari antimikroba. Menurut Green Wood 
(Pratama dan Moch Rachdie, 2005) sensivitas klinik dari mikroba ditentukan dengan tabel klasifikasi sebagai berikut :

Tabel 1. Klasifikasi Respon Hambatan Pertumbuhan Bakteri

\begin{tabular}{|c|c|}
\hline $\begin{array}{c}\text { Diameter Zona } \\
\text { Terang }\end{array}$ & $\begin{array}{c}\text { Respon Hambat } \\
\text { Pertumbuhan }\end{array}$ \\
\hline$\ldots>20 \mathrm{~mm}$ & Kuat \\
\hline $16-20 \mathrm{~mm}$ & Sedang \\
\hline $10-15 \mathrm{~mm}$ & Lemah \\
\hline$\ldots<10 \mathrm{~mm}$ & Sangat Lemah \\
\hline
\end{tabular}

Langkah-langkah penelitian yang akan digunakan yaitu :

\section{a. Pembuatan PCA (Plate Count Agar)}

Menurut Novel, dkk. (2010) pembuatan

PCA adalah sebagai berikut :

1) Siapkan PCA sebanyak 2,25 gr untuk aquades sebanyak $100 \mathrm{cc}$.

2) Campurkan PCA sebanyak 2,25 gr dan aquades $100 \mathrm{cc}$ melalui proses pengadukan dan pemanasan menggunakan hotplate hingga jernih.

3) Siapkan sejumlah tabung reaksi dalam rak tabung ukuran $15 \mathrm{ml}$.

4) Tuangkan larutan PCA tersebut dalam tabung reaksi, kemudian tutup tabung dengan kapas.

5) Letakkan tabung reaksi yang berisi PCA pada beaker glass, kemudian tutup dengan kertas yang terikat oleh gelang karet.

6) Masukan beaker glass ke dalam autoclave, sterilkan selama 15 menit pada tekanan $1 \mathrm{~atm}$ (suhu $121^{\circ} \mathrm{C}$ ).

7) Angkat media setelah proses sterilisasi selesai dan dinginkan.

8) Simpan PCA pada almari es apabila belum dipergunakan.

b. Pembuatan suspensi bakteri

Pembuatan suspensi bakteri streptococus mutans yaitu dengan menyiapkan Natrium Fisiologis 0,98 \% sebanyak $9 \mathrm{ml}$, diletakkan dalam tabung reaksi, kemudian tambahkan 1 swab sampel streptococus mutans dengan cara digores, kemudian dimasukkan dalam tabung reaksi di shaking dan di vortek agar tercampur rata (Novel, dkk. 2010). Kemudian diukur kekeruhan bakteri menggunkan alat densitometer dengan standar kekeruhan 0,5 Mc Farlan atau setara dengan $1,5 \times 10^{8}$ koloni/ ml bakteri (Soemarno, 2002).

c. Pembuatan Konsentrasi Perasan Kulit Jeruk Nipis

Untuk menyatakan komposisi larutan secara kuantitatif digunakan konsentrasi. Konsentrasi perasan kulit jeruk nipis yang dibuat adalah $10 \%, 20 \%, 40 \%$, dan $80 \%$ yang diperoleh dengan cara :

1) Konsentrasi $10 \%=1 \mathrm{ml}$ perasan kulit jeruk nipis dilarutkan ke dalam $9 \mathrm{ml}$ aquades.

2) Konsentrasi $20 \%=2 \mathrm{ml}$ perasan kulit jeruk nipis dilarutkan ke dalam $8 \mathrm{ml}$ aquades.

3) Konsentrasi $40 \%=4 \mathrm{ml}$ perasan kulit jeruk nipis dilarutkan ke dalam $6 \mathrm{ml}$ aquades.

4) Konsentrasi $80 \%=8 \mathrm{ml}$ perasan kulit jeruk nipis dilarutkan ke dalam $2 \mathrm{ml}$ aquades.

d. Teknik Pengaplikasian :

1) Menyiapkan cawan petri steril, masing-masing cawan petri dibagi 4 bagian menggunakan spidol, ditandai X1 (10\% perasan kulit jeruk nipis), X2 (20\% perasan kulit jeruk nipis), X3 (40\% perasan kulit jeruk nipis), X4 (80\% perasan kulit jeruk nipis).

2) Menuang media cair ke dalam cawan petri, kemudian menuangkan suspensi bakteri Sterptococcus mutans.

3) Mengambil paper disk steril dengan menggunakan pinset, celupkan ke dalam perasan kulit jeruk nipis $10 \%$, $20 \%, 40 \%$, dan $80 \%$ kemudian letakkan pada media yang telah beku dengan sedikit tekanan agar menempel sesuai dengan label yang tertulis kemudian tutup kembali cawan petri tersebut dan bungkus dengan kertas lalu diberi etiket.

4) Media kemudian diinkubasi selama 1 x 24 jam dalam inkubator pada suhu $37^{\circ} \mathrm{C}$, kemudian amati hasilnya (Harmita dan Maksum, 2008). 
5) Penelitian dilakukan dengan menentukan jumlah sampel dihitung melalui rumus ulangan Gomez dan Gomez (2007) terlebih dahulu untuk mendapatkan hasil perulangan, rumus ulangan yaitu :

$$
(\mathrm{r} \mathrm{n}-1)-(\mathrm{n}-1) \geq \mathrm{V} 2
$$

Keterangan :

$\mathrm{n}=$ Jumlah sampel

V2 $=$ Derajat bebas galat

$\mathrm{r}=$ Jumlah pengulangan

Sehingga banyaknya pengulangan yang dilakukan pada penelitian ini adalah sebanyak 3 kali. Perlakuan diatas dilakukan sebanyak 3 kali untuk mengetahui reabilitas atau keajegan suatu penelitian. Untuk pengamatan di laboratorium, peneliti dibantu oleh seorang ahli dalam bidang tersebut.

e. Teknik Pengukuran

Setelah di inkubasi kemudian dilihat dan diukur diameter daerah penghambatnya yang disebut oligodinamik (blank zone) dengan menggunakan jangka sorong. Oligodinamik merupakan area daya hambat perasan kulit jeruk nipis terhadap pertumbuhan bakteri Streptococcus mutans. Pengukuran daya hambat dilakukan dari 4 arah yaitu vertikal (diameter I), horizontal (diameter II), diagonal 1 (diameter III), diagonal 2 (diameter IV). Kemudian dirata-rata diameternya.

Adapun skema pengukuran penelitian ini adalah sebagai berikut :

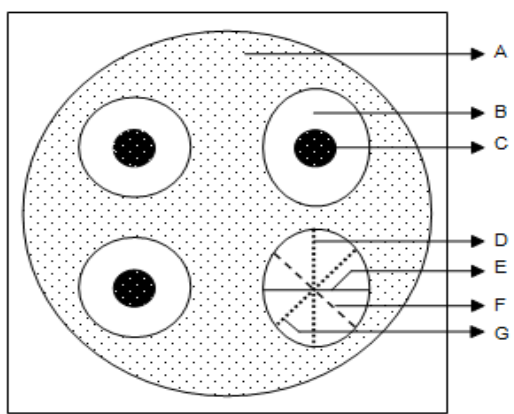

Keterangan :

A : Bakteri

E : Diameter II

B : Oligodinamik

F : Diameter III

C : Paper disk

G : Diameter IV

D : Diameter I

Analisis data dilakukan setelah pengolahan data hasil penelitian. Dalam penelitian ini metode analisa data yang digunakan adalah deskriptif kuantitatif. Untuk mengetahui apakah ada pengaruh perasan kulit jeruk nipis dalam konsentrasi $10 \%, 20 \%, 40 \%$ dan $80 \%$ digunakan analisa analitik dengan pengujian hipotesa Analysis of Variance (ANOVA).

\section{HASIL DAN PEMBAHASAN}

Tabel 2. Daya Hambat Perasan Kulit Jeruk Nipis dengan Konsentrasi 10\%, 20\%, 40\%, dan 80\%

Pada Perlakuan ke-1

\begin{tabular}{|c|c|c|c|c|c|}
\hline \multirow{3}{*}{$\begin{array}{l}\text { Perlakuan } \\
\text { ke- }\end{array}$} & \multirow{3}{*}{$\begin{array}{c}\text { Radius } \\
\text { Oligodinamik } \\
(\mathrm{mm})\end{array}$} & \multicolumn{4}{|c|}{$\begin{array}{c}\text { Perasan Kulit Jeruk Nipis } \\
\text { Konsentrasi }\end{array}$} \\
\hline & & $10 \%$ & $20 \%$ & $40 \%$ & $80 \%$ \\
\hline & & (X1) & $(\mathrm{X} 2)$ & (X3) & $(X 4)$ \\
\hline \multirow{4}{*}{1} & Vertikal & 8,70 & 9,30 & 11,30 & 14,30 \\
\hline & Horizontal & 7,80 & 9,10 & 10,20 & 13,40 \\
\hline & Diagonal I & 7,10 & 9,50 & 9,50 & 14,10 \\
\hline & Diagonal II & 7,30 & 9,30 & 9,80 & 12,10 \\
\hline \multicolumn{2}{|c|}{ Total } & 30,90 & 37,20 & 40,80 & 53,90 \\
\hline \multicolumn{2}{|c|}{ Rata-Rata } & 7,73 & 9,30 & 10,20 & 13,48 \\
\hline
\end{tabular}

Berdasarkan Tabel 2 di atas dapat dijelaskan bahwa hasil pengukuran pada perlakuan ke-1 rata-rata radius oligodinamik daya hambat perasan kulit jeruk nipis yang paling besar adalah konsentrasi $\quad 80 \%$ sebesar $13,48 \mathrm{~mm}$. Sedangkan yang paling kecil adalah konsentrasi $10 \%$ sebesar $7,73 \mathrm{~mm}$. 
Tabel 3. Daya Hambat Perasan Kulit Jeruk Nipis dengan Konsentrasi 10\%, 20\%, 40\%, dan 80\% Pada Perlakuan ke-2

\begin{tabular}{|c|c|c|c|c|c|}
\hline \multirow{2}{*}{$\begin{array}{l}\text { Perlakuan } \\
\text { ke- }\end{array}$} & \multirow{2}{*}{$\begin{array}{c}\text { Radius } \\
\text { Oligodinamik } \\
(\mathrm{mm})\end{array}$} & \multicolumn{4}{|c|}{$\begin{array}{c}\text { Perasan Kulit Jeruk Nipis } \\
\text { Konsentrasi }\end{array}$} \\
\hline & & $\begin{array}{l}10 \% \\
(X 1)\end{array}$ & $\begin{array}{l}20 \% \\
(X 2)\end{array}$ & $\begin{array}{l}40 \% \\
(X 3)\end{array}$ & $\begin{array}{l}80 \% \\
(X 4)\end{array}$ \\
\hline \multirow{4}{*}{ II } & Vertikal & 8,10 & 10,10 & 11,50 & 12,30 \\
\hline & Horizontal & 7,90 & 9,10 & 13,10 & 13,20 \\
\hline & Diagonal I & 8,30 & 8,10 & 12,10 & 12,30 \\
\hline & Diagonal II & 7,90 & 10,20 & 11,20 & 12,50 \\
\hline \multicolumn{2}{|c|}{ Total } & 32,20 & 37,50 & 47,90 & 50,30 \\
\hline \multicolumn{2}{|c|}{ Rata-Rata } & 8,05 & 9,38 & 11,98 & 12,58 \\
\hline
\end{tabular}

Berdasarkan Tabel 3 di atas dapat dijelaskan bahwa hasil pengukuran pada perlakuan ke-2 rata-rata radius oligodinamik daya hambat perasan kulit jeruk nipis yang paling besar adalah konsentrasi $80 \%$ sebesar $12,58 \mathrm{~mm}$. Sedangkan yang paling kecil adalah konsentrasi $10 \%$ sebesar $8,05 \mathrm{~mm}$.

Tabel 4. Daya Hambat Perasan Kulit Jeruk Nipis dengan Konsentrasi 10\%, 20\%, 40\%, dan 80\% Pada Perlakuan ke-3

\begin{tabular}{|c|c|c|c|c|c|}
\hline \multirow{2}{*}{$\begin{array}{l}\text { Perlakuan } \\
\text { ke- }\end{array}$} & \multirow{2}{*}{$\begin{array}{l}\text { Radius } \\
\text { Oligodinamik } \\
(\mathrm{mm})\end{array}$} & \multicolumn{4}{|c|}{$\begin{array}{c}\text { Perasan Kulit Jeruk Nipis } \\
\text { Konsentrasi }\end{array}$} \\
\hline & & $\begin{array}{l}10 \% \\
(X 1)\end{array}$ & $\begin{array}{l}20 \% \\
(X 2)\end{array}$ & $\begin{array}{l}40 \% \\
(X 3)\end{array}$ & $\begin{array}{l}80 \% \\
(X 4)\end{array}$ \\
\hline \multirow{4}{*}{ III } & Vertikal & 7,40 & 8,10 & 9,30 & 13,70 \\
\hline & Horizontal & 7,30 & 9,20 & 9,50 & 12,50 \\
\hline & Diagonal I & 7,60 & 8,70 & 8,80 & 14,90 \\
\hline & Diagonal II & 7,30 & 8,80 & 10,10 & 13,10 \\
\hline \multicolumn{2}{|c|}{ Total } & 29,60 & 34,80 & 37,70 & 54,20 \\
\hline \multicolumn{2}{|c|}{ Rata-Rata } & 7,40 & 8,70 & 9,43 & 13,55 \\
\hline
\end{tabular}

Berdasarkan Tabel 4 di atas dapat dijelaskan bahwa hasil pengukuran pada perlakuan ke-3 rata-rata radius oligodinamik daya hambat perasan kulit jeruk nipis yang paling besar adalah konsentrasi $\quad 80 \%$ sebesar $13,55 \mathrm{~mm}$. Sedangkan yang paling kecil adalah konsentrasi $10 \%$ sebesar $7,40 \mathrm{~mm}$.
Tabel 5. Tabel Rata-rata Total Daya Hambat

Perasan Kulit Jeruk Nipis dengan Konsentrasi $10 \%, 20 \%, 40 \%$, dan $80 \%$

\begin{tabular}{|c|c|c|c|c|}
\hline \multirow{3}{*}{ Perlakuan } & \multicolumn{4}{|c|}{$\begin{array}{r}\text { Rata-rata Diameter Daerah Hambat } \\
\text { (mm) Perasan Kulit Jeruk Nipis }\end{array}$} \\
\cline { 2 - 5 } & \begin{tabular}{c} 
Terhadap Bakteri Streptococcus mutans \\
\cline { 2 - 5 }
\end{tabular} & $\begin{array}{r}20 \% \\
(\mathrm{X} 1)\end{array}$ & $\begin{array}{c}40 \% \\
(\mathrm{X} 2)\end{array}$ & $\begin{array}{c}80 \% \\
(\mathrm{X} 3)\end{array}$ \\
\hline Perlakuan Ke-1 & 7,73 & 9,30 & 10,20 & 13,48 \\
\hline Perlakuan Ke-2 & 8,05 & 9,38 & 11,98 & 12,58 \\
\hline Perlakuan ke-3 & 7,40 & 8,70 & 9,43 & 13,55 \\
\hline Rata-rata Total & 7,73 & 9,13 & 10,54 & 13,20 \\
\hline
\end{tabular}

Berdasarkan Tabel 5 di atas dapat dijelaskan bahwa rata-rata total daya hambat terhadap pertumbuhan bakteri Streptococcus mutans pada perasan kulit jeruk nipis tertinggi adalah $13,20 \mathrm{~mm}$ pada konsentrasi $80 \%$. Perasan kulit jeruk nipis dengan konsentrasi $40 \%$ sebesar $10,54 \mathrm{~mm}$, perasan kulit jeruk nipis dengan konsentrasi $20 \%$ sebesar $9,13 \mathrm{~mm}$ dan rata-rata total daya hambat terhadap pertumbuhan bakteri Streptococcus mutans pada perasan kulit jeruk nipis terendah adalah $7,73 \mathrm{~mm}$ yaitu pada konsentrasi $10 \%$.

Setelah data diperoleh, kemudian diolah menggunakan uji statistik. Dari data tersebut dilakukan uji normalitas data dengan menggunakan pengujian kolmogrov smirnov didapat distribusi data normal. Kemudian selanjutnya dilakukan uji statistik parametrik menggunakan Analysis of Variance (ANOVA). Pada penelitian ini pengaruh konsentrasi perasan kulit jeruk nipis terhadap pertumbuhan bakteri Streptococcus mutans dengan uji Anova didapatkan hasil Sig. $<0,05$, maka $\mathrm{H}_{0}$ ditolak dan $\mathrm{H}_{1}$ diterima. Jadi ada pengaruh konsentrasi perasan kulit jeruk nipis terhadap pertumbuhan bakteri Streptococcus mutans.

Untuk mengetahui perbedaan yang bermakna antar kelompok konsentrasi perasan kulit jeruk nipis dilakukan uji Post Hoc. Hasil dari uji Post Hoc menunjukkan bahwa antar kelompok konsentrasi 10\%, $20 \%, 40 \%$, dan $80 \%$ terdapat perbedaan yang 
bermakna yaitu nilai signifikan antar kelompok konsentrasi lebih kecil dari 0,05. Dari peningkatan nilai tiap konsentrasi tersebut maka ada pengaruh yang bermakna, yaitu ada pengaruh kulit jeruk nipis terhadap daya hambat bakteri Streptococcus mutans.

Perasan kulit jeruk nipis berpengaruh terhadap bakteri Streptococcus mutans. Hal ini disebabkan karena kulit jeruk nipis (Citrus aurantifolia swingle) memiliki kandungan minyak atsiri, yang memiliki sifat antimikroba yang mampu menghambat pertumbuhan bakteri Streptococcus mutans. Selain mengandung minyak atsiri, jeruk nipis juga mempunyai kandungan asam sebesar 7-7,6\%. Asam dapat mendenaturasi protein (protein sel bakteri) dengan cara mengacaukan jembatan garam dengan adanya muatan ionik denaturasi ditandai dengan adanya kekeruhan yang meningkat dan timbulnya gumpalan (Anna, 1994).

Daya antibakteri minyak atsiri jeruk nipis disebabkan oleh adanya senyawa fenol dan turunannya yang dapat mendenaturasi protein sel bakteri. Salah satu senyawa turunan itu adalah kavikol yang memiliki daya bakterisida lima kali lebih kuat dibandingkan fenol. Fenol merupakan senyawa toksik, mengakibatkan struktur tiga dimensi protein terganggu dan terbuka menjadi struktur acak tanpa adanya kerusakan pada struktur kerangka kovalen. Hal ini menyebabkan protein saliva dan bakteri terdenaturasi. Deret asam amino protein tersebut tetap utuh setelah denaturasi, namun aktivitas biologis menjadi rusak sehingga protein tidak dapat melakukan fungsinya (Dea, 2006).

Hasil dari penelitian menunjukkan bahwa perasan kulit jeruk nipis pada konsentrasi 10\%, 20\% mempunyai daya hambat sangat lemah sedangkan pada konsentrasi 40\%, 80\% daya hambat bakteri lemah. Daya hambat lemah kemungkinan disebabkan adanya pengaruh oleh bahan organik asing yang masuk pada cawan petri saat memasukkan suspensi bakteri Streptococcus mutans sehingga akan menurunkan efektivitas kandungan minyak atsiri, fenol dan turunannya dari kulit jeruk nipis. Penggabungan antara zat antimikroba yang dimiliki kulit jeruk nipis dan bahan organik tersebut akan membentuk endapan sehingga zat tersebut tidak lagi mengikat bakteri Streptococcus mutans. Sesuai dengan teori yang dikemukakan oleh Pelczar (2005) yaitu penggabungan antara zat antimikroba tidak lagi mengikat mikroorganisme sehingga terjadi perlindungan yang mengganggu kontak antara zat mikroba dan mikroorganisme.

Hasil dari penelitian yang telah dilakukan, diketahui bahwa Streptococcus mutans sensitif terhadap bahan uji. Dapat diamati dari zona daya hambat yang terlihat terhadap masing-masing konsentrasi mengalami peningkatan. Tetapi perasan kulit jeruk nipis memiliki pengaruh rata-rata total lemah dalam menghambat pertumbuhan bakteri Streptococcus mutans. Hasil yang diperoleh menunjukkan bahwa rata-rata total perasan kulit jeruk nipis mengalami perubahan atau tidak konstan, hal ini dikarenakan faktor teknis yang terjadi pada saat penelitian, yaitu banyaknya larutan yang terserap pada paper disk, sehingga kepekatan paper disk mengalami perbedaan dan berpengaruh pada zona daya hambat. Usaha yang perlu dilakukan agar tidak mengalami hal di atas adalah dengan melakukan percobaan lebih teliti agar memperoleh hasil yang maksimal.

Hasil perlakuan terhadap bakteri Streptococcus mutans menunjukkan bahwa konsentrasi $80 \%$ memiliki zona hambat paling besar dibandingkan pada konsentrasi $10 \%, 20 \%$, dan $40 \%$. Sehingga semakin tinggi konsentrasi larutan maka semakin besar daya hambat terhadap bakteri Streptococcus mutans. Hal ini sesuai dengan Pelczar (1988) mengemukakan bahwa semakin tinggi konsentrasi suatu zat antimikroba semakin tinggi aktivitas antimikrobanya, artinya banyak bakteri akan terbunuh lebih cepat bila konsentrasinya zat tersebut lebih tinggi. Semakin tinggi konsentrasi perasan kulit jeruk nipis yang digunakan maka semakin besar pengaruhnya terhadap pertumbuhan bakteri Streptococcus mutans karena semakin 
banyak kandungan minyak atsiri dalam kulit jeruk nipis yang berperan sebagai antimikroba.

\section{KESIMPULAN}

Berdasarkan hasil penelitian dapat diperoleh kesimpulan sebagai berikut :

1. Ada pengaruh perasan kulit jeruk nipis (Citrus aurantifolia swingle) terhadap pertumbuhan bakteri Streptococcus mutans yaitu semakin tinggi perasan kulit jeruk nipis maka semakin besar pengaruh perasan kulit jeruk nipis terhadap pertumbuhan bakteri Streptococcus mutans.

2. Perasan kulit jeruk nipis memiliki ratarata zona hambat pertumbuhan bakteri Streptococcus mutans yaitu konsentrasi $10 \%$ sebesar $7,73 \mathrm{~mm}$, konsentrasi $20 \%$ sebesar 9,13 mm, konsentrasi 40\% sebesar 10,54 mm, dan konsentrasi $80 \%$ sebesar 13,20 mm. Pada konsentrasi $10 \%, 20 \%$ mempunyai daya hambat sangat lemah sedangkan pada konsentrasi $40 \%$, 80\% daya hambat bakteri lemah.

\section{SARAN}

Setelah dilaksanakan penelitian, maka peneliti ingin menyarankan sebaiknya :

1. Hasil penelitian ini bisa menjadi acuan untuk lebih mengembangkan kulit jeruk nipis khususnya di bidang kesehatan gigi dan mulut karena kulit jeruk nipis memiliki kemampuan dalam menghambat bakteri Streptococcus mutans.

2. Perlu dilakukan penelitian lebih lanjut dengan metode lain dan jenis bakteri yang berbeda.

\section{DAFTAR PUSTAKA}

Ahmed, W., M.A. Pervez, M. Amjad, M. Khalid, C.M. Ayyub and M.A. Nawaz, 2006, Effect of stionic combination on the growth and yield of
Kinnow mandarin (Citrus Reticulata Blanco), Pak. J. Bot., 38(3): 603-612.

Anna Poedjiadi, 1994, Dasar-Dasar Biokimia, Jakarta: Penerbit UI-Press; 78-80.

Depkes RI, 2007, Riskesdas (Riset Kesehatan Dasar), Badan Penelitian dan Pengembangan Kesehatan, Kementrian Kesehatan RI: Jakarta. , 2009, UU RI No 36 Tahun 2009, Depkes RI: Jakarta.

Dwi, P., Makalah Fitokimia Ekstraksi Kulit Jeruk, Akademi Farmasi Putra Indonesia: Semarang

El-Shazy, A.M., and Hussein, K.T., 2004, Chemical Analysis and Biological Activities of Essential Oil of Teuorium leucocladum Boiss (Laminoae), J. Biochemical Systematics and Ecology., 32, 665-674.

Harmita dan Maksum Radji, 2008, Buku Ajar Analisis Hayati, EGC: Jakarta, http://googlebook.com diakses pada tanggal 27 Januari 2014.

Kidd, Edwina A.M., 2012, Dasar-dasar Karies, Penyakit dan Penanggulangan, Penerbit Buku Kedokteran EGC : Jakarta.

Kidd, dan Joyston, 2002, Dasar-Dasar Karies, Penerbit Buku Kedokteran EGC: Jakarta.

Kusumawardani, 2011, Buruknya Kesehatan Gigi dan Mulut, Hanggar: Jakarta.

Madigan, Michael T., dan Martinko, John M., 2005, Brock Biology of Microorganisms, International Microbiology: Vol. 8, Num. 2 (2005); 149-150 01/2010.

Notoatmodjo, Soekidjo, 2012, Metodologi Kesehatan, Aneka Cipta: Jakarta. 
Novel, S., Wulandari, P., Safitri, R., 2010, Praktikum Mikrobiologi Dasar, Cv Trans Info Media: Jakarta

Pelczar, Michael, J., E.C.S Chan, 1988, Dasar - Dasar Mikrobiologi, UI Press: Jakarta.

Pratama, dan Rachdie, Moch., 2005, Pengaruh Ekstrak Serbuk Kayu Siwak (Salvadora persica) Terhadap Pertumbuhan Bakteri Streptococcus mutans dan Staphylococcus aureus dengan Metode Difusi Agar, Skripsi Biologi FMIPA: Institut Teknologi Sepuluh November.

Pratiwi, D., 2007, Gigi Sehat Merawat Gigi Anak Sehari-hari, Kompas: Jakarta.

Sabir, A., 2005, Aktivitas antibakteri flavonoid propolis Trigona sp terhadap bakteri Streptococcus mutans (in vitro), Dental journal 2005. vol. 38. no. 3, pp. 135-141.

Soemarno, 2002, Isolasi danIdentifikasi Bakteri Klinik, Akademi Analis Kesehatan, Departemen Kesehatan RI: Yogyakarta. 